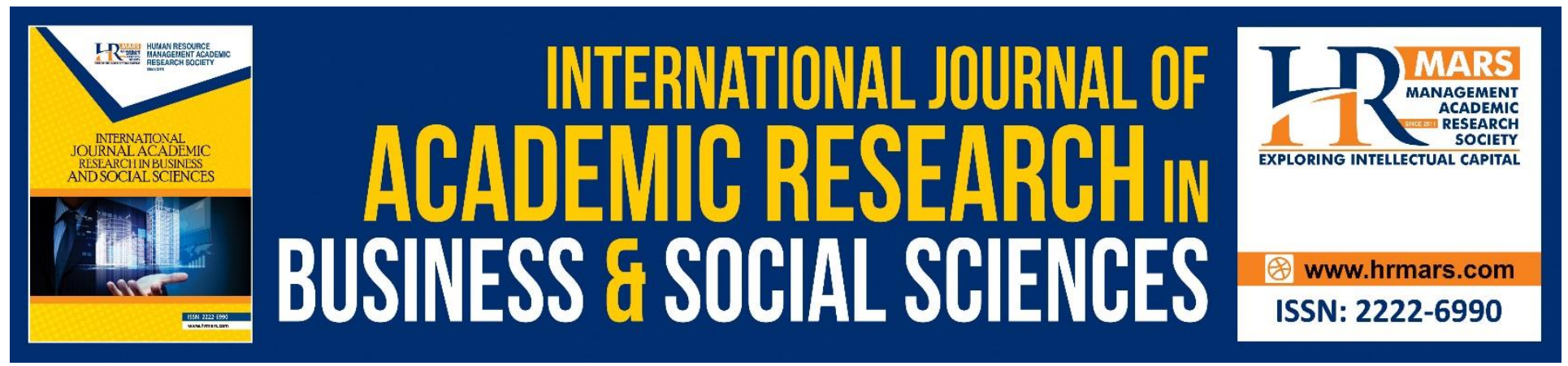

\title{
Investigation of Structural Breaks for Major Stocks in the World
}

\author{
Mehmet SANDAL and Fatih ÇEMREK
}

To Link this Article: http://dx.doi.org/10.6007/IJARBSS/v9-i2/5514

DOI: $10.6007 /$ IJARBSS/v9-i2/5514

Received: 03 Feb 2019, Revised: 24 Feb 2019, Accepted: 04 March 2019

Published Online: 09 March 2019

In-Text Citation: (SANDAL \& ÇEMREK, 2019)

To Cite this Article: SANDAL, M., \& ÇEMREK, F. (2019). Investigation of Structural Breaks for Major Stocks in the World. International Journal of Academic Research in Business and Social Sciences, 9(2), 21-36.

\section{Copyright: (C) 2019 The Author(s)}

Published by Human Resource Management Academic Research Society (www.hrmars.com)

This article is published under the Creative Commons Attribution (CC BY 4.0) license. Anyone may reproduce, distribute, translate and create derivative works of this article (for both commercial and non-commercial purposes), subject to full attribution to the original publication and authors. The full terms of this license may be seen

at: http://creativecommons.org/licences/by/4.0/legalcode

Vol. 9, No. 2, 2019, Pg. 21 - 36

http://hrmars.com/index.php/pages/detail/IJARBSS

JOURNAL HOMEPAGE

Full Terms \& Conditions of access and use can be found at

http://hrmars.com/index.php/pages/detail/publication-ethics 


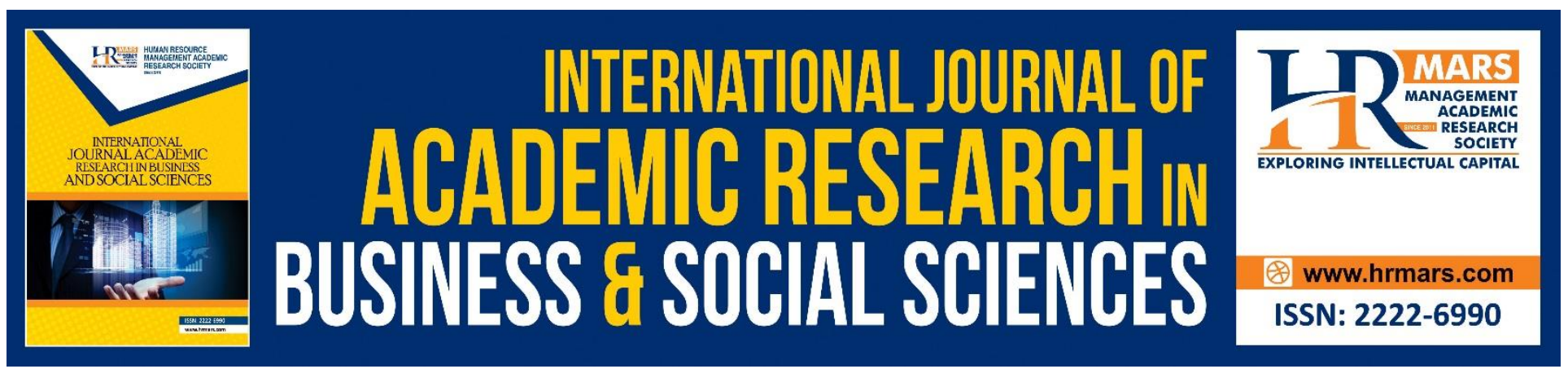

\title{
Investigation of Structural Breaks for Major Stocks in the World
}

\author{
Mehmet SANDAL ${ }^{a}$ and Fatih ÇEMREK ${ }^{b}$ \\ ${ }^{a}$ Department of Econometrics, Faculty of Economics and Administrative Sciences, Manisa Celal \\ Bayar University, Manisa, Turkey \\ ${ }^{b}$ Department of Statistics, Faculty of Science and Letters, Eskişehir Osmangazi University, Eskişehir, \\ Turkey \\ ${ }^{a}$ Corresponding Author: mehmet.sandal@cbu.edu.tr
}

\section{Abstract}

The purpose of this study is to test the stationarity of stock indices in Turkey and some other countries and to investigate whether there are structural breaks. To this end, the study analyses monthly index values of a period from January 2004 to September 2016 for 13 stock indices. The stationarity test for the series analysed is performed with the help of the Augmented Dickey-Fuller (ADF) Unit Root Test. The study also utilizes the Bai-Perron (BP) $(1998,2003)$ information criterion to detect the time of the break.

Keywords: Stock Market, Stationarity, Structural Break, Bai-Perron test, Unit Root Test

\section{Introduction}

Differences or similarities between countries' stock markets arise from causes such as trade volumes of countries with each other, being a member of the same union, being located in the same geographical region, growth rates, monetary and fiscal policies, and political stability and goals. However, countries have been brought much closer by globalization taking place especially since the 1990s, the expanding European Union, growing and developing countries such as China and India, and the increase in world trade volume. As a result, the correlation between stock markets has begun to increase (Korkmaz, Zaman \& Çevik, 2008).

Globalization has changed capital movements, structures and processes. Financial liberalization and the effects of capital movements on national economies following the liberalization as well as the crises experienced have necessarily allowed nations and researchers to focus their attention on the issue. As stock market is an organization that functions most closely to an economically efficient market, it works like a sensor of the market. Thus, the change in stock prices has become an important indicator to estimate market direction (Pekkaya \& Bayramoğlu, 2008). 
Along with the phenomenon of globalization that has developed in the last two decades, significant developments have occurred in financial markets and accordingly in stock markets. A need has emerged to analyse nations' financial markets not only with factors in their own countries but also with factors in the markets of countries they interact with (Boztosun \& Çelik, 2011). This process contributes to the accumulation of resources through the growth and deepening of markets, the canalization of accumulated resources to investments, stronger competition, the emergence of new investment opportunities, the use of resources in more productive and productive areas, the creation of a healthier environment in terms of the distribution and management of risks, and by extension, to financial stability and growth. Financial integration, however, has also caused structural changes in economies. As integration has increased, risks have been diversified, grown and spread more easily, and countries have been easily affected by external developments. Uncertainty or increased risks in a market has been shortly reflected in other markets and price movements (Vuran, 2010).

In classical regression models, structural breaks are among the issues to be considered when examining relations between economic variables. The concept of structural break is a matter that should be considered in time series models as well as in classical regression models. This is due to the fact that if stationarity tests are applied without taking into account a structural break, then they yield inaccurate results. A structural break is a shift that starts at any period in time series of economic variables and persists for a certain period of time (Orhunbilge \& Kuzu, 2014).

Whereas unit root tests have a long history, tests taking into account structural breaks have recently begun to be frequently implemented in recent years. Since there is a high probability of structural breaks during periods of crisis and shock, it is necessary to take into consideration these breaks together with unit root tests in studies on economic series. In case of the presence of such breaks, unit root tests that do not take breaks into account are most likely to yield false information about stationarity. In this case, structural changes occurring in an economy also change the structural characteristics of data which is the indicator of that economy. Therefore, in order to analyse whether these structural changes are influential in the characteristics of time series, it is first necessary to test whether these breaks lead to a shift in the mean and tendency of time series and whether the mean and tendency change the degree of integration of time series (Saatçi \& Dumrul, 2011). In addition, as structural breaks in series lead to a false unit root process, structural break tests must be performed along with unit root tests (Barışık \& Çevik, 2008a).

Against this background, the study aims to test the stationarity of prominent stock indices of Turkey and some other world countries and to investigate whether there are structural breaks. The next section of the study involves a literature review, and the third section introduces the technique used for structural breaks. The fourth section presents the analysis results, and the final section discusses these results.

\section{Literature Review}

Phengpis (2007) explores whether stock market price indices in 17 emerging markets have a unit root. His study adopts a test approach that explains structural breaks in the series and produces stronger results than standard tests. Structural breaks have been found in the stock market prices for 14 countries. 
Barışık and Çevik (2008a) investigate the existence of hysteresis effect in unemployment by using unit root tests and fractional stationarity tests for the annual data of a period from 1923 to 2006. The Augmented Dickey-Fuller (ADF) and the Phillips-Perron (PP) tests reveal first a unit root while the Kwiatkowski, Phillips, Schmidt and Shin (KPSS) test indicates that the series is stationary. They analyse whether there are structural breaks in the period of concern due to the changes in economic policies by using the Zivot-Andrews single- break unit root test and the Bai-Perron (BP) multiple breakpoint test. According to the results of the BP test, there was a structural break in 1967.

In another study involving annual unemployment data for the period from 1923 to 2006, Barışık and Çevik (2008b) analyse hysteresis effect with structural break tests by using a different approach. The break tests used in the analysis found a break in 1968. Unit root tests and semiparametric long memory models proved the existence of hysteresis effect. Accordingly, the study has revealed that hysteresis effect should be taken into consideration in the struggle against unemployment.

Kazi et al. (2011) examine the contagion effect between the stock markets of the U.S and sixteen OECD countries during 2002-2009. They administered the Bai-Perron $(1998,2003)$ structural break test for the identification of breakpoint due to the Global Financial Crisis of 2007-2009. The study has revealed the existence of contagion between the stock markets of the US and the OECD.

Büberkökü (2015) investigates the weak-form efficiency of the stock markets in Turkey by considering multiple structural breaks. The study deploys BIST100, BIST30, BIST Financials, BIST Industrial and BIST Services indices and examines whether the series have structural breaks. Upon the detection of structural changes in the series, the Bai-Perron $(1998,2003)$ is used to determine the number of structural breaks. The number of structural breaks in the series has been detected based on the Bai-Perron $(1998,2003)$ test, Bayesian information criterion (BIC), and SEQFT test statistics.

\section{STRUCTURAL BREAK TESTS}

The concept of structural break is one of the topics on which a vast number of propositions have been developed in time series econometrics. In particular, single break and multiple breaks in time series, and known and unknown breakpoints have served as the starting point for developed tests (Dilişen, 2007).

Perron (1989) asserted that unit root tests to be carried out without considering structural changes would produce erroneous results. He further pointed out that standard ADF tests showed a tendency to assess stationary series as non-stationary in the case of structural breaks (Carrion-iSilvestre et al., 2009; Göçer et al., 2013; Göçer et al., 2015). For that reason, he suggested an alternative unit root test taking structural changes into consideration. Structural break unit root tests initiated by Perron (1989) have been studied by Zivot-Andrews (1992), Perron (1997), Ng-Perron (2001) and Lee-Strazicich (2003) using different algorithms. In these methods, one or two structural breaks are allowed in series. However, Bai and Perron (2003) and Carrion-i-Silvestre et al. (2009) have proposed tests that can determine multiple structural breaks (Göçer and Peker, 2014a, 2014b; Göçer, 2015). 


\section{Bai-Perron (1998) Multiple Structural Break Analysis}

Bai-Perron (1998) multiple structural breakpoint test is a method based on the internal determination of structural breaks in series rather than unit root test (ilgün, 2010). This test approach developed by Bai and Perron (1998) for the determination of multiple structural breaks is based on the following multiple linear regression model with $m$ breaks estimated by the method of least squares:

$$
y_{t}=x_{t}^{\prime} \beta+z_{t}^{\prime} \delta_{j}+u_{t} \quad t=T_{j-1}+1, \ldots ., T_{j} \quad j=1, \ldots, m
$$

where $y_{t}$ is the observed dependent variable; both $x_{t}$ and $z_{t}$ are vectors of covariates with dimensions $p \times 1$ and $q \times 1$, respectively; $\beta$ and $\delta_{j}$ are vectors of coefficients; $T_{1}, \ldots, T_{m}$ are unknown breakpoints; and $u_{t}$ is the disturbance term.

In the Bai-Perron (1998) test, the main goal is to estimate unknown regression coefficients and breakpoints together (Göktaş, 2008). This test uses a method that is based on dynamic programming algorithm and provides global minimization of the sum of squared residuals. Thus, this test enables estimation of unknown regression coefficients $\beta$ and $\delta_{j}$ by minimizing the sum of squared residuals for each $m$ partition through the method of least squares (Barışık and Çevik, 2008a, 2008b; Illgün, 2010). However, three test approaches proposed by Bai and Perron $(1998,2003)$ are considered to determine the number of breaks:

$\checkmark \operatorname{SupF}_{t}(k)$ : The statistics test the null hypothesis of no break and the alternative hypothesis of $k$ number of breaks.

$\checkmark \operatorname{UDMax}_{t}(M, q)$ and $\operatorname{WDMaxF}_{t}(M, q)$ : The statistics test the null hypothesis of no break and the alternative hypothesis of an unknown number of breaks with maximum " $m$ " number breaks.

$\checkmark \operatorname{SupF}_{t}(l+1 / l)$ : The statistics test the null hypothesis of $l$ break and the alternative hypothesis of $l+1$ breaks.

Table 1: Hypotheses for Bai-Perron multiple structural break analysis

\begin{tabular}{cccc}
\hline Hypothesis & $\operatorname{SupF}_{t}(k)$ & $\operatorname{UDMaxF}_{t}(M, q)$ ve $\operatorname{WDMaxF}_{t}(M, q)$ & $\operatorname{SupF}_{t}(l+1 / l)$ \\
\hline$H_{0}$ hypothesis & $\begin{array}{c}\text { No break } \\
\text { k number of } \\
\text { breaks }\end{array}$ & No break & $l$ break \\
$H_{1}$ hypothesis & Unknown number of break & $l+1$ breaks \\
\hline
\end{tabular}

For these three cases used in determining the number of breaks, Bai and Perron (2003) highlights that $\operatorname{SupF}_{t}(k), \operatorname{UDMax}_{t}(M, q)$ and $\operatorname{WDMaxF}_{t}(M, q)$ test statistics must first be analysed, at least one structural break will be present if the null hypothesis is rejected, and thus, $\operatorname{SupF}_{t}(l+1 / l)$ test statistics is appropriate to use after these steps to determine the total number of breaks after these steps (İ̧̧i et al., 2016).

Bai and Perron (2003) also suggest the use of the modified LWZ information criterion, the Bayesian Information Criterion (BIC) and the sequential model selection criterion based on the sequential supFT $(I+1 \mid /)$ test (Bai and Perron, 2003; Barışık and Çevik, 2008a; Göktaş, 2008; Çevik and Erdoğan, 2009; Illgün, 2010). Depending on the information criteria, the number of structural breaks 
INTERNATIONAL JOURNAL OF ACADEMIC RESEARCH IN BUSINESS AND SOCIAL SCIENCES

Vol. 9, No. 2, Feb, 2019, E-ISSN: 2222-6990 C 2019 HRMARS

can also be determined by the point where the BIC and LWZ criteria have minimum values (Büberkökü, 2015).

\section{Results}

\section{Research Data}

The present study on the structural breaks of world's prominent stock market indices investigates monthly index values in Turkey, United States (USA), Italy, England, Germany, France, Switzerland, Portugal and Belgium for the period of January 2004-September 2016. As the series of index values are monthly, the series are separated from the seasonal effects and the logarithms of the series free from seasonal effects are subtracted and analysed. The indices used in the present study are listed according to their international abbreviations.
Euronext Amsterdam $\rightarrow$ AEX
Euronext Brussel $\rightarrow$ BEL20
Istanbul Stock Exchange $\rightarrow$ BIST100
Euronext Paris $\rightarrow$ CAC40
Frankfurt Stock Exchange $\rightarrow$ DAX
London Stock Exchange $\rightarrow$ FTSE100
Nasdaq $100 \rightarrow$ NASDAQ

\begin{abstract}
Italian Stock Exchange $\rightarrow$ FTSEMIB
Hong Kong Stock Exchange $\rightarrow \mathrm{HSI}$

Tokyo Stock Exchange $\rightarrow$ NIKKEI

New York Stock Exchange $\rightarrow$ NYSE

Euronext Lisbon $\rightarrow$ PSI20

Swiss Market Index $\rightarrow$ SMI
\end{abstract}

\section{Unit Root Test}

A stationary time series is defined as one whose mean and variance are constant over time and which is based on the probability process where the covariance depends not on the calculation period but only on the distance between two periods. The possibility to obtain significant correlations between variables also depends on whether series are stationary (Gujarati, 1999). A stationarity test is carried out to determine whether the series of concern are stationary, that is to say, whether the series has a unit root. Dickey-Fuller (DF) and Augmented Dickey-Fuller (ADF) tests are often used to determine the existence of a unit root exists and to investigate the stationarity of time series (Kutlar, 2007). The ADF unit root test was employed to test the stationarity of the series of stock market index variables investigated in the present study. The test results are shown in Table 2.

Table 2: ADF unit root test results at the level form

\begin{tabular}{|c|c|c|c|c|}
\hline Variables & Model & $\begin{array}{l}\text { ADF test } \\
\text { statistics }\end{array}$ & $\begin{array}{l}\text { MacKinno } \\
\text { n statistics }\end{array}$ & $\begin{array}{c}\text { Significan } \\
\text { ce value }\end{array}$ \\
\hline \multirow{3}{*}{$A E X$} & $\begin{array}{l}\text { Non-intercept and Non- } \\
\text { Trend Model }\end{array}$ & $0,372(0)$ & $-1,943$ & 0,7906 \\
\hline & Intercept model & $\begin{array}{c}-1,729 \\
(1)\end{array}$ & $-2,881$ & 0,4146 \\
\hline & Intercept and trend model & $\begin{array}{c}-1,742 \\
(1) \\
\end{array}$ & $-3,440$ & 0,7279 \\
\hline \multirow{2}{*}{$B E L 20$} & $\begin{array}{l}\text { Non-intercept and Non- } \\
\text { Trend Model }\end{array}$ & $0,309(4)$ & $-1,943$ & 0,7738 \\
\hline & Intercept model & $\begin{array}{c}-2,513 \\
(4)\end{array}$ & $-2,881$ & 0,1145 \\
\hline
\end{tabular}


INTERNATIONAL JOURNAL OF ACADEMIC RESEARCH IN BUSINESS AND SOCIAL SCIENCES Vol. 9, No. 2, Feb, 2019, E-ISSN: $2222-6990$ ๑ 2019 HRMARS

\begin{tabular}{|c|c|c|c|c|}
\hline & Intercept and trend model & $\begin{array}{c}-2,523 \\
(4)\end{array}$ & $-3,440$ & 0,3148 \\
\hline \multirow{3}{*}{ BisT100 } & $\begin{array}{l}\text { Non-intercept and Non- } \\
\text { Trend Model }\end{array}$ & $1,491(0)$ & $-1,943$ & 0,9662 \\
\hline & Intercept model & $\begin{array}{c}-2,266 \\
(0)\end{array}$ & $-2,881$ & 0,1844 \\
\hline & Intercept and trend model & $\begin{array}{c}-2,556 \\
(0)\end{array}$ & $-3,440$ & 0,3011 \\
\hline \multirow{3}{*}{ CAC4O } & $\begin{array}{l}\text { Non-intercept and Non- } \\
\text { Trend Model }\end{array}$ & $0,318(0)$ & $-1,943$ & 0,7762 \\
\hline & Intercept model & $\begin{array}{c}-1,654 \\
(0)\end{array}$ & $-2,881$ & 0,4526 \\
\hline & Intercept and trend model & $\begin{array}{c}-1,664 \\
(0) \\
\end{array}$ & $-3,440$ & 0,7625 \\
\hline \multirow{3}{*}{$D A X$} & $\begin{array}{l}\text { Non-intercept and Non- } \\
\text { Trend Model }\end{array}$ & $1,498(0)$ & $-1,943$ & 0,9667 \\
\hline & Intercept model & $\begin{array}{c}-1,119 \\
(0)\end{array}$ & $-2,881$ & 0,7074 \\
\hline & Intercept and trend model & $\begin{array}{c}-2,333 \\
(1)\end{array}$ & $-3,440$ & 0,4134 \\
\hline \multirow{3}{*}{ FTSE100 } & $\begin{array}{l}\text { Non-intercept and Non- } \\
\text { Trend Model }\end{array}$ & $0,993(0)$ & $-1,943$ & 0,9150 \\
\hline & Intercept model & $\begin{array}{c}-1,802 \\
(0)\end{array}$ & $-2,881$ & 0,3784 \\
\hline & Intercept and trend model & $\begin{array}{c}-2,094 \\
(0) \\
\end{array}$ & $-3,440$ & 0,5448 \\
\hline \multirow{3}{*}{ FTSEMIB } & $\begin{array}{l}\text { Non-intercept and Non- } \\
\text { Trend Model }\end{array}$ & $\begin{array}{l}-0,759 \\
(0)\end{array}$ & $-1,943$ & 0,3859 \\
\hline & Intercept model & $\begin{array}{c}-0,879 \\
(0)\end{array}$ & $-2,881$ & 0,7925 \\
\hline & Intercept and trend model & $\begin{array}{c}-1,738 \\
(0)\end{array}$ & $-3,440$ & 0,7294 \\
\hline \multirow{3}{*}{$H S i$} & $\begin{array}{l}\text { Non-intercept and Non- } \\
\text { Trend Model }\end{array}$ & $0,705(0)$ & $-1,943$ & 0,8665 \\
\hline & Intercept model & $\begin{array}{c}-2,235 \\
(1)\end{array}$ & $-2,881$ & 0,1950 \\
\hline & Intercept and trend model & $\begin{array}{c}-2,750 \\
(1)\end{array}$ & $-3,440$ & 0,2183 \\
\hline \multirow[t]{2}{*}{ NASDAQ } & $\begin{array}{l}\text { Non-intercept and Non- } \\
\text { Trend Model }\end{array}$ & $1,919(0)$ & $-1,943$ & 0,9868 \\
\hline & Intercept model & $0,106(0)$ & $-2,881$ & 0,9653 \\
\hline
\end{tabular}


INTERNATIONAL JOURNAL OF ACADEMIC RESEARCH IN BUSINESS AND SOCIAL SCIENCES Vol. 9, No. 2, Feb, 2019, E-ISSN: $2222-6990$ ๑ 2019 HRMARS

\begin{tabular}{|c|c|c|c|c|}
\hline & Intercept and trend model & $\begin{array}{c}-1,977 \\
(0) \\
\end{array}$ & $-3,440$ & 0,6089 \\
\hline \multirow{3}{*}{ NIKKEI } & $\begin{array}{l}\text { Non-intercept and Non- } \\
\text { Trend Model }\end{array}$ & $0,457(1)$ & $-1,943$ & 0,8121 \\
\hline & Intercept model & $\begin{array}{c}-1,421 \\
(1)\end{array}$ & $-2,881$ & 0,5704 \\
\hline & Intercept and trend model & $\begin{array}{c}-1,508 \\
(1) \\
\end{array}$ & $-3,440$ & 0,8228 \\
\hline \multirow{3}{*}{ NYSE } & $\begin{array}{l}\text { Non-intercept and Non- } \\
\text { Trend Model }\end{array}$ & $\begin{array}{c}-0,374 \\
(0) \\
\end{array}$ & $-1,943$ & 0,5482 \\
\hline & Intercept model & $\begin{array}{c}-1,457 \\
(0)\end{array}$ & $-2,881$ & 0,5528 \\
\hline & Intercept and trend model & $\begin{array}{c}-1,357 \\
(0) \\
\end{array}$ & $-3,440$ & 0,8696 \\
\hline \multirow{3}{*}{ PSi20 } & $\begin{array}{l}\text { Non-intercept and Non- } \\
\text { Trend Model }\end{array}$ & $\begin{array}{c}-0,635 \\
(0) \\
\end{array}$ & $-1,943$ & 0,4409 \\
\hline & Intercept model & $\begin{array}{l}-0,988 \\
(1)\end{array}$ & $-2,881$ & 0,7569 \\
\hline & Intercept and trend model & $\begin{array}{c}-2,232 \\
(1) \\
\end{array}$ & $-3,440$ & 0,4682 \\
\hline \multirow{3}{*}{ SMi } & $\begin{array}{l}\text { Non-intercept and Non- } \\
\text { Trend Model }\end{array}$ & $0,561(1)$ & $-1,943$ & 0,8364 \\
\hline & Intercept model & $\begin{array}{c}-1,668 \\
(1)\end{array}$ & $-2,881$ & 0,4457 \\
\hline & Intercept and trend model & $\begin{array}{c}-1,719 \\
(1) \\
\end{array}$ & $-3,440$ & 0,7384 \\
\hline
\end{tabular}

As seen in Table 2, according to the ADF test testing the null hypothesis that "a unit root is present" or "the series is non-stationary", all test results generated for the three cases including "Non-intercept and Non-Trend Model", "Intercept Model", and "Intercept and Trend Model" were found to be significant at the significance level of 5\%. Accordingly, the series of 13 indices analysed are non-stationary at the level form, that is, they have a unit root. Table 3 shows the results of the stationarity test made by taking first differences of all the series. 
INTERNATIONAL JOURNAL OF ACADEMIC RESEARCH IN BUSINESS AND SOCIAL SCIENCES Vol. 9, No. 2, Feb, 2019, E-ISSN: $2222-6990$ ๑ 2019 HRMARS

Table 3: ADF unit root test results in the first-difference case

\begin{tabular}{|c|c|c|c|c|}
\hline Variables & Model & $\begin{array}{l}\text { ADF test } \\
\text { statistics }\end{array}$ & $\begin{array}{l}\text { MacKinno } \\
\text { n statistics }\end{array}$ & $\begin{array}{c}\text { Significan } \\
\text { ce value }\end{array}$ \\
\hline \multirow{3}{*}{$A E X$} & $\begin{array}{l}\text { Non-intercept and Non- } \\
\text { Trend Model }\end{array}$ & $\begin{array}{c}-10,315 \\
(0) \\
\end{array}$ & $-1,943$ & $P<0,001$ \\
\hline & Intercept model & $\begin{array}{c}-10,289 \\
(0) \\
\end{array}$ & $-2,881$ & $P<0,001$ \\
\hline & Intercept and trend model & $\begin{array}{c}-10,263 \\
(0)\end{array}$ & $-3,440$ & $P<0,001$ \\
\hline \multirow{3}{*}{$B E L 20$} & $\begin{array}{l}\text { Non-intercept and Non- } \\
\text { Trend Model }\end{array}$ & $\begin{array}{c}-3,765 \\
(3) \\
\end{array}$ & $-1,943$ & 0,0002 \\
\hline & Intercept model & $\begin{array}{c}-3,772 \\
(3)\end{array}$ & $-2,881$ & 0,0040 \\
\hline & Intercept and trend model & $\begin{array}{c}-3,760 \\
(3)\end{array}$ & $-3,440$ & 0,0215 \\
\hline \multirow{3}{*}{ BIST100 } & $\begin{array}{l}\text { Non-intercept and Non- } \\
\text { Trend Model }\end{array}$ & $\begin{array}{c}-11,063 \\
(0)\end{array}$ & $-1,943$ & $P<0,001$ \\
\hline & Intercept model & $\begin{array}{c}-11,169 \\
(0) \\
\end{array}$ & $-2,881$ & $P<0,001$ \\
\hline & Intercept and trend model & $\begin{array}{c}-11,205 \\
(0)\end{array}$ & $-3,440$ & $P<0,001$ \\
\hline \multirow{3}{*}{ CAC4O } & $\begin{array}{l}\text { Non-intercept and Non- } \\
\text { Trend Model }\end{array}$ & $\begin{array}{c}-10,518 \\
(0)\end{array}$ & $-1,943$ & $P<0,001$ \\
\hline & Intercept model & $\begin{array}{c}-10,489 \\
(0) \\
\end{array}$ & $-2,881$ & $P<0,001$ \\
\hline & Intercept and trend model & $\begin{array}{c}-10,454 \\
(0)\end{array}$ & $-3,440$ & $P<0,001$ \\
\hline \multirow{3}{*}{$D A X$} & $\begin{array}{l}\text { Non-intercept and Non- } \\
\text { Trend Model }\end{array}$ & $\begin{array}{c}-10,384 \\
(0)\end{array}$ & $-1,943$ & $\mathrm{P}<0,001$ \\
\hline & Intercept model & $\begin{array}{c}-10,492 \\
(0)\end{array}$ & $-2,881$ & $P<0,001$ \\
\hline & Intercept and trend model & $\begin{array}{c}-10,458 \\
(0)\end{array}$ & $-3,440$ & $P<0,001$ \\
\hline \multirow{3}{*}{ FTSE100 } & $\begin{array}{l}\text { Non-intercept and Non- } \\
\text { Trend Model }\end{array}$ & $\begin{array}{c}-11,545 \\
(0)\end{array}$ & $-1,943$ & $P<0,001$ \\
\hline & Intercept model & $\begin{array}{c}-11,578 \\
(0)\end{array}$ & $-2,881$ & $P<0,001$ \\
\hline & Intercept and trend model & $\begin{array}{c}-11,540 \\
(0)\end{array}$ & $-3,440$ & $P<0,001$ \\
\hline FTSEMIB & $\begin{array}{l}\text { Non-intercept and Non- } \\
\text { Trend Model }\end{array}$ & $\begin{array}{c}-10,434 \\
(0)\end{array}$ & $-1,943$ & $P<0,001$ \\
\hline
\end{tabular}


INTERNATIONAL JOURNAL OF ACADEMIC RESEARCH IN BUSINESS AND SOCIAL SCIENCES Vol. 9, No. 2, Feb, 2019, E-ISSN: $2222-6990$ ๑ 2019 HRMARS

\begin{tabular}{|c|c|c|c|c|}
\hline & Intercept model & $\begin{array}{c}-10,434 \\
(0)\end{array}$ & $-2,881$ & $P<0,001$ \\
\hline & Intercept and trend model & $\begin{array}{c}-10,410 \\
(0)\end{array}$ & $-3,440$ & $P<0,001$ \\
\hline \multirow{3}{*}{$H S i$} & $\begin{array}{l}\text { Non-intercept and Non- } \\
\text { Trend Model }\end{array}$ & $\begin{array}{c}-10,393 \\
(0)\end{array}$ & $-1,943$ & $P<0,001$ \\
\hline & Intercept model & $\begin{array}{c}-10,386 \\
(0) \\
\end{array}$ & $-2,881$ & $P<0,001$ \\
\hline & Intercept and trend model & $\begin{array}{c}-10,358 \\
(0)\end{array}$ & $-3,440$ & $P<0,001$ \\
\hline \multirow{3}{*}{ NASDAQ } & $\begin{array}{l}\text { Non-intercept and Non- } \\
\text { Trend Model }\end{array}$ & $\begin{array}{c}-10,627 \\
(0)\end{array}$ & $-1,943$ & $P<0,001$ \\
\hline & Intercept model & $\begin{array}{c}-10,827 \\
(0) \\
\end{array}$ & $-2,881$ & $P<0,001$ \\
\hline & Intercept and trend model & $\begin{array}{c}-10,852 \\
(0)\end{array}$ & $-3,440$ & $P<0,001$ \\
\hline \multirow{3}{*}{ NIKKEI } & $\begin{array}{l}\text { Non-intercept and Non- } \\
\text { Trend Model }\end{array}$ & $\begin{array}{c}-10,222 \\
(0)\end{array}$ & $-1,943$ & $P<0,001$ \\
\hline & Intercept model & $\begin{array}{c}-10,208 \\
(0)\end{array}$ & $-2,881$ & $P<0,001$ \\
\hline & Intercept and trend model & $\begin{array}{c}-10,180 \\
(0)\end{array}$ & $-3,440$ & $P<0,001$ \\
\hline \multirow{3}{*}{ NYSE } & $\begin{array}{l}\text { Non-intercept and Non- } \\
\text { Trend Model }\end{array}$ & $\begin{array}{c}-12,199 \\
(0)\end{array}$ & $-1,943$ & $P<0,001$ \\
\hline & Intercept model & $\begin{array}{c}-12,158 \\
(0)\end{array}$ & $-2,881$ & $P<0,001$ \\
\hline & Intercept and trend model & $\begin{array}{c}-12,145 \\
(0) \\
\end{array}$ & $-3,440$ & $P<0,001$ \\
\hline \multirow{3}{*}{ PSi20 } & $\begin{array}{l}\text { Non-intercept and Non- } \\
\text { Trend Model }\end{array}$ & $\begin{array}{c}-10,376 \\
(0)\end{array}$ & $-1,943$ & $P<0,001$ \\
\hline & Intercept model & $\begin{array}{c}-10,374 \\
(0) \\
\end{array}$ & $-2,881$ & $P<0,001$ \\
\hline & Intercept and trend model & $\begin{array}{c}-10,397 \\
(0) \\
\end{array}$ & $-3,440$ & $P<0,001$ \\
\hline \multirow{3}{*}{ SMi } & $\begin{array}{l}\text { Non-intercept and Non- } \\
\text { Trend Model }\end{array}$ & $\begin{array}{c}-9,677 \\
(0)\end{array}$ & $-1,943$ & $P<0,001$ \\
\hline & Intercept model & $\begin{array}{c}-9,674 \\
(0) \\
\end{array}$ & $-2,881$ & $\mathrm{P}<0,001$ \\
\hline & Intercept and trend model & $\begin{array}{c}-9,645 \\
(0)\end{array}$ & $-3,440$ & $P<0,001$ \\
\hline
\end{tabular}


INTERNATIONAL JOURNAL OF ACADEMIC RESEARCH IN BUSINESS AND SOCIAL SCIENCES Vol. 9, No. 2, Feb, 2019, E-ISSN: $2222-6990$ ๑ 2019 HRMARS

As seen in Table 3, according to the ADF test testing the null hypothesis that "a unit root is present" or "the series is non-stationary", the test results were found to be insignificant at the significance level of 5\%. Accordingly, the series of 13 indices analysed are stationary at the first level.

In the present study, the multiple structural break test developed by Bai and Perron (2003) was conducted in order to test whether there are structural breaks in the series of the stock market indices analysed. Table 2 shows the results of $\operatorname{SupF}_{t}(k)$ statistics testing the null hypothesis of "no break" against the alternative hypothesis of "k number of breaks".

Table 4: Bai-Perron Test Results

\begin{tabular}{cccccccc}
\hline & Sup $F_{T}(1)$ & Sup $F_{T}(2)$ & Sup $F_{T}(3)$ & Sup $F_{T}(4)$ & $\begin{array}{c}\text { Sup } \\
F_{T}(5)\end{array}$ & UDMax & WDMax \\
\hline $\begin{array}{c}\text { Bai-Perron } \\
\text { Value }\end{array}$ & 8,58 & 7,22 & 5,96 & 4,99 & 3,91 & 8,88 & 9,91 \\
\hline AEX & 0,504 & 5,321 & 5,798 & $8,190^{*}$ & $11,977^{*}$ & $11,977^{*}$ & $26,282^{*}$ \\
BEL20 & 0,588 & 6,840 & $6,561^{*}$ & $8,104^{*}$ & $8,475^{*}$ & 8,475 & $18,597^{*}$ \\
BiST100 & $12,343^{*}$ & $11,628^{*}$ & $18,084^{*}$ & $17,342^{*}$ & $19,558^{*}$ & $19,558^{*}$ & $42,919 *$ \\
CAC40 & 1,346 & $8,341^{*}$ & $7,940^{*}$ & $7,157^{*}$ & $7,914^{*}$ & 8,341 & $17,367^{*}$ \\
DAX & $9,846^{*}$ & $7,704^{*}$ & $9,132^{*}$ & $16,660^{*}$ & $20,523^{*}$ & $20,523^{*}$ & $45,035^{*}$ \\
FTSE100 & 7,143 & 3,840 & 2,028 & $13,157^{*}$ & $18,426^{*}$ & $18,426^{*}$ & $40,434^{*}$ \\
FTSEMiB & 5,828 & $9,317^{*}$ & $19,080^{*}$ & $17,030^{*}$ & $7,424^{*}$ & $19,080^{*}$ & $29,283^{*}$ \\
HSi & 4,286 & $8,001^{*}$ & 0,862 & 1,047 & 1,085 & 8,001 & 9,508 \\
NASDAQ & 7,067 & $33,604^{*}$ & $29,382^{*}$ & $68,921^{*}$ & 159,162 & 159,162 & 349,261 \\
NiKKEi & 2,247 & $21,985^{*}$ & $15,737^{*}$ & $32,208^{*}$ & $30,999^{*}$ & $32,208^{*}$ & $68,025^{*}$ \\
NYSE & 0,645 & $26,901^{*}$ & $18,534^{*}$ & $14,015^{*}$ & 161,349 & 161,349 & 354,059 \\
PSi20 & 4,280 & 3,905 & $11,002^{*}$ & $15,804^{*}$ & $11,480^{*}$ & 15,804 & $27,174 *$ \\
SMi & 1,631 & $7,687^{*}$ & $9,167^{*}$ & $7,063^{*}$ & $7,619 *$ & $9,167^{*}$ & $16,718^{*}$ \\
\hline
\end{tabular}

According to Table 4, considering $\operatorname{SupF}_{t}(k)$ test statistics for the significance level of 5\%; $\operatorname{SupF}_{t}(1), \operatorname{SupF}_{t}(3), \operatorname{SupF}_{t}(4)$ and $\operatorname{SupF}_{t}(5)$ statistics were found to be insignificant for HIS index value; $\operatorname{SupF}_{t}(1), \operatorname{SupF}_{t}(2)$ and $\operatorname{SupF}_{t}(3)$ statistics were insignificant for AEX and FTSE100 index values; $\operatorname{SupF}_{t}(1)$ and $\operatorname{SupF}_{t}(2)$ statistics were insignificant for BEL20 and PSI20 index values; $\operatorname{SupF}_{t}(1)$ statistic was insignificant for CAC40, FTSEMIB, NASDAQ100, NIKKEI, NYSE and SMI index values. However, the results for $k$ values other than the test statistics finding these indices as insignificant were found to be significant. In addition, the $\operatorname{SupF}_{t}(k)$ test statistic of BIST100 and DAX indices was found to be significant at the significance level of $5 \%$ for all $k$ values.

Based on the results of $\operatorname{UDMax}_{t}(M, q)$ and $\operatorname{WDMaxF}_{t}(M, q)$ test statistics testing the null hypothesis of no break against the alternative hypothesis of an unknown number of breaks with maximum " $M$ "number breaks, $\operatorname{UDMaxF}_{t}(M, q)$ test statistic was found to be insignificant for BEL20 
INTERNATIONAL JOURNAL OF ACADEMIC RESEARCH IN BUSINESS AND SOCIAL SCIENCES

Vol. 9, No. 2, Feb, 2019, E-ISSN: 2222-6990 C 2019 HRMARS

and CAC40 variables whereas $\operatorname{WDMaxF}_{t}(M, q)$ test statistics was significant. While both test statistics were found to be insignificant for HIS index value, they were significant for the other index variables.

Table 5 shows the results of $\operatorname{SupF}_{t}(l+1 / l)$ test statistics testing the null hypothesis of " $l$ break" against the alternative hypothesis of $l+1$ breaks in order to determine the number and date of structural breaks in the series as well as the results of the LWZ information criterion, the BIC and the sequential information criterion.

Table5: $\operatorname{SupF}_{t}(l+1 / l)$ test statistics results

\begin{tabular}{cccccc}
\hline & Sup & Sup & Sup & BIC & LWZ \\
& $\boldsymbol{F}_{T}(\mathbf{1} / \mathbf{0})$ & $\boldsymbol{F}_{T}(\mathbf{2} / \mathbf{1})$ & $\boldsymbol{F}_{T}(\mathbf{3} / \mathbf{2})$ & & \\
\hline Bai-Perron Value & 8,58 & 10,13 & 11,14 & & 4 \\
\hline AEX & 0,504 & ----- & ---- & 4 & 3 \\
BEL20 & 0,588 & ---- & ---- & 4 & 4 \\
BiST100 & $12,343^{*}$ & $28,655^{*}$ & 3,011 & 4 & 3 \\
CAC40 & 1,346 & ----- & ---- & 3 & 4 \\
DAX & $9,846^{*}$ & 7,102 & ---- & 5 & 4 \\
FTSE100 & 7,143 & ----- & ---- & 4 & 3 \\
FTSEMiB & 5,822 & ---- & ---- & 4 & 5 \\
HSi & 4,286 & ---- & ---- & 3 & 4 \\
NASDAQ & 7,067 & ---- & ---- & 5 & 2 \\
NiKKEi & 2,247 & ---- & ---- & 4 & 4 \\
NYSE & 0,645 & ---- & ---- & 3 & 3 \\
PSi20 & 4,280 & ---- & ---- & 4 & 3 \\
SMi & 1,631 & ---- & ---- & 3
\end{tabular}

As seen in Table 5, while $\operatorname{SupF}_{t}(l+1 / l)$ statistics of AEX, BEL20, CAC40, FTSE100, FTSEMIB, HSI, NASDAQ, NIKKEI, NYSE, PSI20 and SMI index values were found to be insignificant for $\mathrm{l}=0$ at the significance level of $5 \%, \operatorname{SupF}_{t}(l+1 / l)$ statistic of DAX index value was significant for I=0 but insignificant for $\mathrm{I}=1$. $\operatorname{SupF}_{t}(l+1 / l)$ statistic of BIST100 index value was found to be significant for $\mathrm{l}=0,1$ but insignificant for $\mathrm{I}=2$.

As a result, the study accepted the null hypothesis testing the existence of one break for DAX index variable and the null hypothesis testing the existence of two breaks for BIST100 index variable by using $\operatorname{SupF}_{t}(l+1 / l)$ test statistics. According to the BIC in Table 5, the number of breaks is 5 and 4 for DAX and BIST100 index variables, respectively while the LWZ information criterion shows that both variables have 4 breaks. However, Bai and Perron (2003) suggest that the sequential test outperforms the BIC and LWZ. Thus, examining the test results together, the study found that DAX index value had one structural break on "2012M12" and BIST100 index value had two structural breaks on "2009M12" and "2012M10". 


\section{Conclusions and Recommendations}

Various physical and economic situations occurring in the world affect, directly or indirectly, national stock markets and may lead to some breaks along with financial crises. The purpose of the present study is to test the stationarity of Turkish stock market indices in and some other world's prominent stock market indices and to investigate whether these indices had structural breaks. To this end, the study analysed the monthly index values of the period from January 2004 to September 2016 for the stock market indices of Turkey, United States (USA), Italy, England, Germany, France, Switzerland, Portugal and Belgium. The stationarity test for the series of these stock index variables was conducted with the ADF unit root test for the series, and all the series was accordingly found to be non-stationary at the level form. As a result of the ADF unit test results repeated by taking the first differences of the series, all values were found to be stationary. Thus, whether there were structural breaks in the non-stationary series at the level form was investigated with the Bai-Perron (1998) structural break unit root analysis.

The analysis performed based on the three test approaches proposed by Bai and Perron $(1998,2003)$ first analysed $\operatorname{SupF}_{t}(k)$ statistics. According to the results of $\operatorname{SupF}_{t}(k)$, BIST100 and DAX index values were found to be significant for all $k$ values. In addition, other index values were found to be insignificant for some $k$ values and significant for other $k$ values. Hence, the null hypothesis of no break was rejected for all the series and the existence of $k$ number of breaks was determined.

$\operatorname{UDMax}_{t}(M, q)$ and $\operatorname{WDMaxF}_{t}(M, q)$ test statistics were employed to determine whether there was at least one structural break. While both test statistics were found to be insignificant for $\mathrm{HSI}$ index value, at least one of both test statistics was found to be significant for other index values. Thus, whereas the null hypothesis for HSI index value was not rejected at the significance level of $5 \%$, the null hypothesis for other variables was rejected and there was an unknown number of breaks. In this case, it is possible to say that there is at least one structural break in the series.

$\operatorname{SupF}_{t}(l+1 / l)$ test statistics, the BIC, the LWS information criterion, and the sequential information criterion were used to investigate the number and date of the structural breaks in the series. $\operatorname{SupF}_{t}(l+1 / l)$ test statistics showed that DAX index variable had one break and BIST100 index value had two breaks. Besides, as the BP (2003) sequential test outperforms compared to the BIC and the LWS information criterion, the BP (2003) sequential test information criterion was taken into consideration. In this case, DAX index value had one structural break on "2012M12" and BIST100 index value had two structural breaks on "2009M12" and "2012M10". Ural and Küçüközmen (2011) determined that there were structural breaks for the stock market index of the five countries examined. In the studies of Anlaş and Toraman (2016), Büberbökü (2015) and Günay (2014), structural breaks were observed on the BIST100 index for the investigated periods. On the contrary, Şimşek (2016) concluded that there was no structural break for the BIST100 index.

In econometric series-based research, it is crucial to examine the structure of the series and to determine whether the series have breaks since structural breaks in the series of concern lead to a false unit root and erroneous results. It is thought that there may be more than one structural break in the series examined. Therefore, it is aimed to determine multiple structural breaks in this study. 
The theory of Bai-Perron test for detection of multiple structural breaks was explained and applied to various stock market index values.

This study provides information about structural breaks in studies to be conducted based on stock markets for researchers. Moreover, the study evaluated a combination of the world's prominent stock market indices. Therefore, it is important to investigate whether or not there are common breaks. Further studies are needed to investigate the cointegrating especially taking into account the structural breaks in DAX and BIST100 indices. In addition, the study emphasizes the importance of structural breaks in the investigation of long-term relationships. Considering structural breaks will increase the significance of econometric analysis.

\section{References}

Anlaş, T. \& Toraman, C. (2016). Analysing the efficiency of the Turkish stock market with multiple structural breaks. International Journal of Academic Research in Business and Social Sciences, 6(12), 721-740.

Bai, J. \& Perron, P. (1998). Estimating and testing linear models with multiple structural changes. Econometrica, 66(1), 47-78.

Bai, J. \& Perron, P. (2003). Computation and analysis of multiple structural change models. Journal of Applied Econometrics, 18(1), 1-22.

Barışık, S. \& Çevik, E.i. (2008a). Analysis of unemployment hysteresis in Turkey using structural breaks tests: the period of 1923-2006. KMU Journal of Social and Economic Research, 10(14), 109-134.

Barışık, S. \& Çevik, E.I. (2008b). Hysteresis effect in unemployment: long memory model. http://www.kamu-is.org.tr/. 9(4), 1-36.

Boztosun, D. \& Çelik, T. (2011). Cointegration analysis of Turkish Stock Exchange with European Stock Exchanges. Suleyman Demirel University The Journal of Faculty of Economics and Administrative Sciences, 16(1), 147-162.

Büberbökü, Ö. (2015). Examining the efficiency of the Turkish Stock Market: A multiple structural break analysis. Bankacılar Dergisi, 93, 46-59.

Carrion-i-Silvestre, J.L., Kim, D. \& Perron, P. (2009). GLS-Based unit root tests with multiple structural breaks under both the null and the alternative hypotheses. Econometric Theory, 25(6), 1754-1792.

Çevik, E.i. \& Erdoğan, S. (2009). Efficiency of banking sector stock market: structural break and long memory. Doğuş University Journal, 10(1), 26-40.

Dilişen, B. (2007). Unit Root Tests for Structural Break With An Application. Marmara University Institute of Social Sciences, Master's Thesis, İstanbul, Turkey.

Göçer, İ., Mercan, M. \& Peker, O. (2013). Kredi hacmi artışının cari açığa etkisi: çoklu yapısal kırılmalı eşbütünleşme analizi. Ekonometri ve İstatistik, 18, 1-17.

Göçer, I. \& Peker, O. (2014a). Foreign direct investments' effect on the employment: cointegration analysis with multiple structural breaks in Turkey, China and India sample. Journal of Management and Economics, 21(1), 107-123.

Göçer, I. \& Peker, O. (2014b). Foreign direct investments' effects on the balance of current account: cointegration analysis with multiple structural breaks in Turkey, China and India sample. Journal of BRSA Banking and Financial Markets, 8(1), 87-116. 
INTERNATIONAL JOURNAL OF ACADEMIC RESEARCH IN BUSINESS AND SOCIAL SCIENCES

Vol. 9, No. 2, Feb, 2019, E-ISSN: $2222-6990$ ๑ 2019 HRMARS

Göçer, i., Mercan, M. \& Bölükbaş, M. (2015). Effects on employment and economic growth of banking sector loans: cointegration analysis with multiple structural breaks for Turkish economy. Hacettepe University Journal of Economics and Administrative Sciences, 33(2), 65-84.

Göçer, i. (2015). Effects of banking sector credit volume expansion on unemployment: cointegration analysis with multiple structural breaks. The Journal of Industrial Relations \& Human Resources, 17(2), 109-129.

Göktaş, Ö. (2008). Türkiye ekonomisinde bütçe açığının sürdürülebilirliğinin analizi. İstanbul Üniversitesi Iktisat Fakültesi Ekonometri ve Istatistik Dergisi, 8, 45-64.

Gujarati, D.N. (1999). Basic Econometrics. $4^{\text {nd }}$ Edition, Mc Graw-Hill Education.

Günay, S. (2014). Long memory analysis of the BiST-100 index volatility inclusive of structural breaks. Journal of Yasar University, 9(36), 6261-6380.

ilgün, M.F. (2010). The bases of expansionary fiscal contraction hypothesis and an application on Turkish economy. Erciyes University Journal of Economics and Administrative Sciences, 35, 233-253.

İşi, A., Çemrek, F. \& Polat, H. (2016). Investigation of the private pension system using multiple structural breaks analysis in Turkey. Academic Sight International Refereed Online Journal of Social Sciences, 53, 24-37.

Kazi, I.A., Guesmi, K. \& Kaabia, O. (2011). Contagion effect of financial crisis on OECD stock markets. Economics Discussion Papers No. 2011-15: 1-19. (Accessed 2 September 2016), Available from: http://www.economicsejournal.org/economics/discussionpapers/2011-15.

Korkmaz, T., Zaman, S. \& Çevik, E.I. (2008). The Integration relationship between ISE and the countries which have a high trade volume with Turkey and European union equity markets. International Journal of Management Economics and Business, 4(8), 19-44.

Kutlar, A. (2007). Ekonometriye Giriş. Ankara: Nobel Publisher.

Lee, J. \& Strazicich, M.C. (2003). Minimum lagrange multiplier unit root test with two structural breaks. The Review of Economics and Statistics, 85(4), 1082-1089.

$\mathrm{Ng}, \mathrm{S}$. \& Perron, P. (2001). Lag length selection and the construction of unit root tests with good size and power. Econometrica, 69(6), 1519-1554.

Orhunbilge, A.N. \& Kuzu, S. (2014). Research into the long-run relationship among the economic variables of Turkish manufacturing industry considering the structural breaks. Kafkas University Journal of Economics and Administrative Sciences Faculty, 5(7), 1-18.

Pekkaya, M. \& Bayramoğlu, M.F. (2008). Causality test between exchange rate and stock prices: an analysis on Usd/Ytl, ISE 100 and S\&P 500. Journal Of Accounting And Finance, 38, 163-176.

Perron, P. (1989). The great crash, the oil price shock, and the unit root hypothesis. Econometrica, 57(2), 1361-1401.

Perron, P. (1997). Further evidence on breaking trend functions in macroeconomic variables. Journal of Econometrics, 80(2), 355-385.

Phengpis, C. (2007). Are emerging stock market price indices really stationary? Applied Financial Economics, 16(13), 931-939.

Saatçi, M. \& Dumrul, Y. (2011). The relationship between economic growth and environmental pollution: the estimation of environmental kuznets curve with a cointegration analysis of structural breaks for Turkish economy. Erciyes University Journal of Economics and Administrative Sciences, 37, 65-86. 
Şimşek, M. (2016). An investigation on the relationship between Istanbul Stock Exchange (BIST) and the stock exchanges of BRICS countries. Journal of the Human and Social Science Researches, 5(3), $520-536$.

Ural, M. \& Küçüközmen, C.C. (2011). Analyzing the dual long memory in stock market returns. Ege Academic Review, 11, 19-28.

Vuran, B. (2010). The determination of long-run relationship between ISE 100 and international equity indices using cointegration analysis. Istanbul University Journal of the School of Business Administration, 39(1), 154-168.

Zivot, E. \& Andrews, D. (1992). Further evidence on the great crash, the oil-price shock and the unitroot hypothesis. Journal of Business Economic Statistics, 10(3), 251-270. 